\title{
PENINGKATAN KETERAMPILAN MAHASISWA DALAM MEMBUAT MEDIA PEMBELAJARAN PAI MELALUI METODE GUIDED DISCOVERY LEARNING
}

\author{
(Studi Kasus program Lesson Study pada Mahasiswa FAI Semester V mata kuliah Media \\ Pembelajaran PAI)
}

Muyasaroh, M.Pd.I

muyasarohbox@gmail.com

\begin{abstract}
Abstrak
Tujuan pendidikan diantarannya adalah mencetak manusia yang cakap, terampil, kreatif dan mandiri. Sebagai calon guru, mahasiswa PAI seharusnya terampil dan kreatif dalam segala bidang. Diharapkan dari sikap kreatif tersebut mahasiswa terampil dalam membuat media pembelajaran. Karena media pembelajaran yang baik dapat memotivasi siswa dalam belajar.Pengimplementasian metode Guided Discovery Learning pada proses pembelajaran diharapkan mampu meningkatkan keterampilan mahasiswa. Karena implementasi metode ini memfokuskan pada siswa aktif, menemukan konsep dengan berdiskusi dan mencoba menciptakan karya. Sedangkan dosen sebagai fasilitator dan pembimbing. Oleh karena itu penelitian ini ingin merumuskan masalah bagaimana peningkatan keterampilan mahasiswa dalam membuat media pembelajaran PAI melalui metode Guided discovery Guidance Learning. merupakan suatu metode pembelajaran yang menitik beratkan pada aktivitas siswa dalam belajar. Guru bertindak sebagai pembimbing dan fasilitator yang mengarahkan siswa untuk menemukan konsep, melalui tukar pendapat, berdiskusi, membaca sendiri dan mencoba sendiri.Adapun jenis penelitian adalah ( Field Research) dan berupa PTK karena penelitian dilakukan berdasarkan pengalaman peneliti pada program Lesson study. Program Lesson Study ini ada 4 siklus dan tiap siklus terdiri dari Plan, Do dan See atau Refleksi. Penelitian ini menggunkan teknik pengumpulan data yaitu Observasi dan Dokumentasi. Analysis data menggunakan data reductions, data display, dan conclusion drawing /verification.. Hasil dari penelitian ini adalah melalui metode discovery Guided Learning mahasiswa mampu meningkatkan keterampilan mahasiswa dalam membuat media Pembelajaran PAI dengan indicator- indikator kecepatan waktu, kesesuaian antara media dan materi yang akan disampaikan dan bentuk dari media yang dihasilkan sangat variatif.
\end{abstract}

Key word : Ketrampilan, media dan metode Guided Disovery Learning.

\subsection{Latarbelakang Masalah}

Pendidikan nasional berfungsi mengembangkan kemampuan dan membentuk watak serta peradaban bangsa yang bermartabat dalam rangka mencerdaskan kehidupan bangsa, bertujuan untuk berkembangnya potensi peserta didik agar menjadi manusia yang 
beriman dan bertakwa kepada Tuhan Yang Maha Esa, berakhlak mulia, sehat, berilmu, cakap, kreatif, mandiri, dan menjadi warga negara yang demokratis serta bertanggung jawab. ${ }^{1}$ Jadi Tujuan pendidikan tidak hanya ingin mencetak siswa menjadi cerdas dan pintar, namun harus membekali siwa dengan kreatifitas dan kemandirian. Diharapkan melalui keterampilan- keterampilan membuat keberadaan seseorang akan semakin kreatif ditengah masyarakat. Salah satu keterampilan sebagai calon guru pendidikan agama Islam, yaitu guru dituntut bisa membuat dan menggunakan /mengoprasikan media pembelajaran PAI dan Guru sekurang-kurangnya dapat menggunakan alat yang sederhana, dan mudah didapat sebagai keharusan dalam upaya mencapai tujuan pengajaran yang diharapkan.

Selain itu, Media pembelajaran merupakan salah satu aspek penting dalam proses pembelajaran. Hamalik mengemukakan bahwa pemakaian media pengajaran dalam proses belajar mengajar dapat membangkitkan keinginan dan minat yang baru, membangkitkan motivasi dan rangsangan kegiatan belajar, dan bahkan membawa pengaruh-pengaruh psikologis terhadap $\operatorname{siswa}^{2}$. Oleh karena itu penggunaan media pembelajaran diharapkan mampu mencapai tujuan pembelajaran secara maksimal.

Menurut Nadler (1986:73) pengertian keterampilan (skill) adalah kegiatan yang memerlukan praktek atau dapat diartikan sebagai implikasi dari aktivitas. Menurut Dunnette (1976:33) pengertian keterampilan adalah kapasitas yang dibutuhkan untuk melaksanakan beberapa tugas yang merupakan pengembangan dari hasil training dan pengalaman yang didapat. ${ }^{3}$ selain itu mengidentifikasi adanya empat aspek atau variabel yang mencirikan keterampilan. Keempat aspek itu adalah kecepatan, akurasi, bentuk, dan kesesuaian. Artinya,

\footnotetext{
${ }^{1}$ Undang-Undang Republik Indonesia, No.20 Tahun 2003 tentang Sistem Pendidikan Nasional. BAB II pasal 3.

${ }^{2}$ Azhar Arsyad, Media Pembelajaran. (Jakarta : Raja Grafindo Persada, 2007). hal. 4

${ }^{3}$ http://cyber-dakhlan90.blogspot.co.id/2012/09/keterampilan-dan-nilai-sebagai-materi.html Senin, 1 Desember 2014.
} 
pertama keterampilan harus ditampilkan dalam batasan waktu tertentu, yang menunjukkan bahwa semakin cepat semakin baik. Kedua keterampilan harus menunjukkan akurasi yang tinggi sesuai dengan yang ditargetkan. Ketiga keterampilan pun harus dilaksanakan dengan kebutuhan energi yang minimal; (form atau bentuk menunjuk pada usaha yang ekonomis). Dan terakhir, keterampilan pun harus juga adaptif, yaitu tetap cakap meskipun di bawah kondisi yang berbeda-beda ${ }^{4}$

Jadi keterampilan adalah kegiatan yang memerlukan praktek dalam menyelesaikan tugas dari hasil training dan pengalaman dengan identifikasi aspek kecepatan, akurasi, bentuk dan ketepatan. Sedangkan metode pembelajaran discovery (penemuan) adalah metode mengajar yang mengatur pengajaran sedemikian rupa sehingga anak memperoleh pengetahuan yang sebelumnya belum diketahuinya. ${ }^{5}$ Dalama metode discovery learning dosen/guru dituntut untuk memberikan skema pembelajaran yang mengarahkan mahasiswa memperoleh sendiri konsep, prinsip atau menciptakan karya dosen /guru berperan dalam memfasilitasi siswa yang menginginkan keterangan dan pengarahan apabila terjdi mis konsepsi. Jadi guru masih memberikan bimbingan sehingga metode ini masih bersifat guidance bimbingan.

Berdasarkan beberapa penjelasan diatas, penulis ingin mengetahui bagaimana peningkatan keterampilan mahasiswa dalam membuat media pembelajaran PAI melalui metode Guided discovery Guidance learning (Studi Kasus program Lesson Study pada Mahasiswa FAI Semester V mata kuliah Media Pembelajaran PAI).

\footnotetext{
${ }^{4}$ http://kangmr.blogspot.co.id/2011/08/pengertian-keterampilanmacam-macam.html, senin, 1 Desember 2014

${ }^{5}$ NurHaniyah dan Muhammad Jauhar, Strategi Belajar-Mengajar di Kelas.( Jakarta : Prestasi Pustaka, 2014), hal 180
} 


\subsection{Rumusan Masalah}

Rumusan masalah dalam penelitian ini adalah "bagaimana peningkatan keterampilan mahasiswa dalam membuat media pembelajaran PAI melalui metode Guided discovery Guidance learning ?

\subsection{Tujuan Penelitian}

Tujuan penelitian ini adalahi mengetahui bagaimana peningkatan keterampilan mahasiswa dalam membuat media pembelajaran PAI melalui metode Guided discovery Guidance learning

\subsection{Manfaat Penelitian}

\subsubsection{Secara Teoritis}

Penelitian ini diharapkan dapat menambah khazanah ilmu pengetahuan dibidang metode pembelajaran pada umumnya. Selian itu dapat dijadikan dasar penelitian lebih lanjut dan sebagai bahan pustaka di Universitas Muhammadiyah Gresik pada khususnya.

\subsubsection{Secara Praktis}

Sebagai kewajiban penelitian internal pada setiap dosen sebagai bentuk pelaksanaan Tri Darma Perguruan Tinggi.

\subsection{Metode Penelitian}

\subsubsection{Jenis Penelitian}


Penelitian ini termasuk jenis penelitian lapangan ( Field Research ) berupa Penelitian Tindakan Kelas atau PTK karena penelitian diadakan pada program kegiatan Lesson Study. Selain itu bisa disebut penelitian deskriptif karena merupakan penelitian terhadap fenomena tertentu untuk menjelaskan aspek-aspek yang relevan dengan fenomena atau masalah yang ada. Pada umumnya penelitian deskriptif tidak menggunakan hipotesis(non hipotesis) sehingga dalam penelitiannya tidak perlu merumuskan hipotesis. ${ }^{6}$

\subsubsection{Pendekatan Penelitian}

Pendekatan penelitian adalah metode atau cara mengadakan penelitian. ${ }^{7}$ Sedangkan jenis pendekatan pada penelitian ini adalah pendekatan fenomenologis. Konsep utama dalam fenomenologi adalah makna. Makna merupakan isi penting yang muncul dari pengalaman kesadaran manusia. peneliti mendapatkan data yang akurat dan orientik langsung dari informan sekaligus terlibat langsung dalam pelaksanaan Lesson Study dan data tidak perlu dikuantifikasikan. Berupa data peningkatan keterampilan membuat media pembelajaran PAI.

\subsubsection{Obyek dan Subyek Penelitian}

Objek kajian dalam penelitian ini adalah kegiatan pembelajaran pada program Lesson Study, oleh dosen Pendidikan Agama Islam Universitas Muhammadiyah Gresik.

\footnotetext{
${ }^{6}$ Ibid, hal 245

${ }^{7}$ Suharsimi Arikunto, Prosedur Penelitian : Suatu pendekatan Praktek, (Jakarta : Rineka Cipta 2002), Hal. 23
} 
Sedangkan subyek penelitian merupakan informan yang mengetahui program Lesson Study.

\subsubsection{Teknik Pengumpulan Data}

Penelitian ini menggunakan beberapa teknik pengumpulan data, diantaranya adalah :

1. Metode Observasi

Observasi adalah alat pengumpulan data dengan cara mengamati dan mencatat secara sistematik gejala-gejala yang diselidiki. ${ }^{8}$ Teknik pengumpulan data dengan observasi ini dilakukan karena berkenaan dengan prilaku manusia dan proses kerja dan jumlah responden tidak terlalu besar. Metode observasi ini mengambil data tentang peningkatan keterampilan mahasiswa dalam membuat media pembelajaran PAI sesuai dengan pengamatan di lapangan.

Jenis observasi yang dilakukan peneliti adalah observasi berperan serta (participant observation), peneliti terlibat dengan kegiatan sehari-hari orang yang sedang diamati atau yang digunakan sebagai sumber data penelitian. Sambil melakukan pengamatan, peneliti ikut melakukan apa yang dikerjakan oleh sumber data, dan ikut merasakan suka dukanya. Dengan observasi partisipan ini, maka data yang diperoleh akan lebih lengkap, tajam dan sampai mengetahui pada tingkat makna dari setiap prilaku yang tampak. ${ }^{9}$

2. Metode Dokumentasi

${ }^{8}$ Cholid Marbuko dan Abu Ahmadi, Metodologi Penelitian (Jakarta: Bumi Aksara,1997), hal.23

${ }^{9}$ Prof. Dr. Sugiyono. Metode Penelitian Pendidikan Pendekatan Kuantitatif, Kualitatif dan R\&D.(Bandung : Alfa Beta 2010), hal. 204 
Metode dokumentasi adalah cara memperoleh data mengenai hal-hal atau fariabel yang berupa catatan, tarnskrip, buku, surat kabar dan sebagainya. ${ }^{10}$ Metode ini digunakan untuk mengambil data tentang hasil moneving terkait metode yang digunakan dosen dalam proses pembelajaran, selain itu data tentang daftar mahasiswa dan data dosen yang mengikuti kegiatan Lesson Study.

\subsubsection{Teknik Analisis Data}

Teknik analisis data yang digunakan dalam penelitian kualitatif ini adalah analisis data model miles dan Huberman yaitu : data reductions, data display, dan conclusion drawing /verification.

Gambar.1. Komponen Dalam Analisis Data ${ }^{11}$

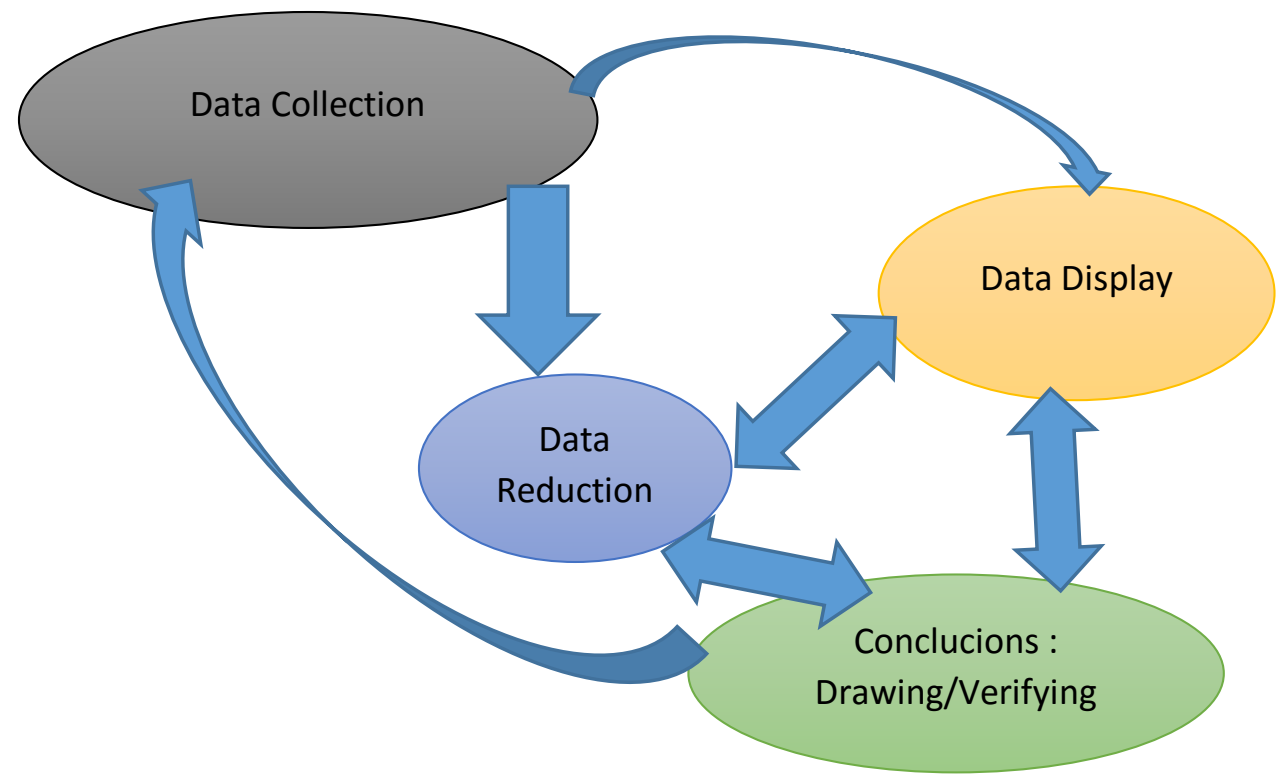

Peneliti menggunakan analisis ini Karena sesuai dengan tema dan proses

penelitian. Bermula dari pengumpulan data maka langka pertama dalam analisis data

${ }^{10}$ Suharsimi Arikunto, Metodologi Penelitian Suatu Pendekatan Praktis (Jakarta : PT.Rineka Cipta 1997), hal 67

${ }^{11}$ Prof. Dr. Sugiyono. Metode Penelitian ...., hal. 337 
adalah peneliti mereduksi data berarti merangkum, memilih hal-hal yang pokok, memfokuskan pada hal-hal yang penting, dicari tema dan polanya dan membuang yang tidak perlu. Setelah data direduksi maka langkah ke dua adalah Data Display penyajian data. Dalam penelitian data kualitatif penyajian data bisa dilakukan dalam bentuk uraian singkat, bagan, hubungan antar kategori flowchart dan sejenisnya yang bersifat naratif. "the most ftequent form of disply data for qualitative research data in the past has been narrative tex". Yang paling sering digunakan dalam penelitian kualitatif adalah dengan teks yang bersifat naratif. ${ }^{12}$

Langkah ketiga adalah penarikan kesimpulan dan verifikasi. Kesimpulan dalam penelitian kualitatif dapat menjawab rumusan masalah yang dirumuskan sejak awal apabila didukung oleh bukti-bukti yang valid dan konsisten saat peneliti kelapangan mengumpulkan data, maka kesimpulan yang dikemukakan merupakan kesimpulan yang kredibel. ${ }^{13}$

Secara garis besar peneliti mengumpulkan data dari hasil pelaksanaan Lesson study berupa hasil observasi dan dokumentasi, selanjutnya mereduksi data sesuai dengan tema implementasi metode Discovery Guided Learning dan keterampilan mahasiswa dalam membuat media pembelajaran PAI. Selanjutnya peneliti melakukan penyajian data dengan mengelompokkan indicator adanya peningkatan keterampilan membuat media pembelajarn PAI melalui metode Discovery Guided Learning dari pengolahan data observasi. Langka senjautnya adalah menarik kesimpulan dengan memberikan bukti-bukti peningkatan

\footnotetext{
12 Prof. Dr. Sugiyono. Metode Penelitian ....., hal 341

${ }^{13}$ Suharsimi Arikunto, Metodologi..................i, hal 345
} 
keterampilan mahasiswa dalam membuat media pembelajaran PAI melalui metode Discovery Guided Learning.

\section{BAB II KAJIAN PUSTAKA}

\subsection{Penelitian Sebelumnya}

Adapun penelitian sebelumnya yang akan peneliti gunakan sebagai pijakan antara lain dari penelitian saudari Siti Muthoharoh berupa skripsi dengan judul "pengaruh model Guided Discovery Learning Terhadap Hasil Belajar Kimia Siswa Pada Konsep Laju Reaksi (quasi Eksperimen di SMAN 72 Jakarta Utara)" sebagai tugas akhir dalam menyelesaikan S1 di UIN Syarif Hidayatullah Tahun 2011. Dalam kesimpulannya dikatakan bahwa terdapat pengaruh antara Guided Discovery Learning terhadap hasil belajar kimia pada konsep laju reaksi. ${ }^{14}$ Selain itu penelitin dari hasil artikel dari prosiding oleh Moh. Kanzunudin, Eka Zuliana dan Hery Suryo Kuntoro Dosen Program Studi PGSD FKIP Universitas Muria Kudus. Dengan judul "Peranan Metode Guided Discovery Learning Perbantuan Lembar Kegiatan Siswa Dalam Peningkatan Prestasi Belajar Matematika”. Kesimpulan dalam penelitian ini adalah Peranan Metode Guided Discovery Learning Perbantuan Lembar Kegiatan Siswa yang dilaknsanakan di kelas V SDN 5 Dersalam dapat meningkatkan prestasi belajar siswa pada materi volum kubus dan balok. ${ }^{15}$ Berbeda dengan penelitian yang sudah ada

\footnotetext{
${ }^{14}$ http://repository.uinjkt.ac.id/dspace/bitstream/123456789/5033/1/101668-SITI\%2OMUTOHAROH-FITK.PDF Selasa, 2 Desember 2014

${ }^{15}$ Moh. Kanzunnudin, Dkk, (Prosiding seminar Nasional: 30 Maret 2013)

http://eprints.umk.ac.id/3504/3/ARTIKEL_PROSIDING 2013.pdf, Selasa, 8 Desember 2014.
} 
tersebut, karena peneliti ingin memfokuskan pada peningkatan keterampilan mahasiswa dalam membuat media pembelajaran PAI melalui metode Guided Discovery Learning.

\subsection{Landasan teori}

\subsubsection{Metode Pembelajaran}

Penggunaan metode pada proses pembelajaran sangat urgen sebagai upaya dalam pencapaian tujuan pembelajaran.

\subsubsection{Pengertian Metode Pembelajaran}

Metode pembelajaran merupakan cara mengajar yang disusun berdasarkan prinsip dan system tertentu. ${ }^{16}$ pembelajaran dapat berlangsung dengan efektif jika metode yang digunakan dapat menyampaikan materi secara komperhensif kepada siswa.. Adapun definisi metode pembelajaran menurut para ahli berikut ini :

Surakhmad W mengemukakan metode adalah cara yang didalam fungsinya merupakan alat untuk mencapai suatu tujuan ${ }^{17}$

Menurut Nana Sudjana metode pembelajaran adalah cara yang dipergunakan guru dalam mengadakan hubungan dengan siswa pada saat berlangsungnya pengajaran. ${ }^{18}$

\subsubsection{Fungsi Metode Pembelajaran}

\footnotetext{
${ }^{16}$ Ridwan Abdullah Sani , Inovasi Pembelajaran.(Jakarta PT : Bumi Aksara, 2013), hal 90

${ }^{17}$ Surahmad w. Metodologi Pengajaran Nasional,(Bandung : Jemmars), hal. 75

${ }^{18}$ Sudjana, Nana dan Ahmad Rivai, Media Pembelajaran. (Bandung : Sinar Baru Algensindo 2010), hal. 76
} 
Metode pembelajaran memiliki beberapa fungsi dalam proses pembelajaran. Menurut Hatimah metode pembelajaran tidak hanya berfungsi sebagai cara untuk menyampaikan materi saja, melainkan berfungsi juga untuk pemberian dorongan, pengungkap tumbuhnya minat belajar, penyampaian bahan mengajar, pencipta iklim belajar yang kondusif, tenaga untuk melahirkan kretifitas, pendorong untuk penilaian diri dalam proses dan hasil belajar dan pendorong dalam melengkapi kelemahan hasil belajar ${ }^{19}$

\subsubsection{Metode Discovery Guided Learning}

Metode pembelajaran adalah cara yang digunakan dalam menyampaikan materi pembelajaran. Sedangkan metode pembelajaran discovery (penemuan) adalah metode mengajar yang mengatur pengajaran sedemikian rupa sehingga anak memperoleh pengetahuan yang sebelumnya belum diketahuinya. ${ }^{20}$ Metode discovery ini menekankan pada keaktifan siswa dalam pembelajaran, sedangkan guru berperan sebagai pendamping atau fasilitator.

Adapun ciri utama dalam metode discovery adalah

1. Mengeksplorasi dan memecahkan masalah untuk menciptakan, menggabungkan dan mengeneralisasi pengetahuan.

2. Berpusat pada siswa

3. Kegiatan untuk menggabungkan pengetahuan baru dan pengetahuan yang sudah ada

\footnotetext{
${ }^{19}$ Hatimah, Strategi dan Metode Pembelajaran, ( Bandung : Adira, 2000), hal. 10

${ }^{20}$ Moh. Kanzunnudin, Dkk, (Prosiding seminar Nasional: 30 Maret 2013) hal.180
} 
Metode discovery ini menekankan tugas guru yakni menyiapkan lembar tugas pada siswa (study case) selain itu guru memberikan kebebasan siswa untuk memberikan ide /kreatifitas siswa dalam menemukan solusi dari permasalahan tersebut. Guru berperan mengarahkan /fasilitator.Berikut ini langkah-langkah umum dari pembelajaran discovery Learning ;

1. Mengidentifikasi kebutuhan siswa.

2. Menyeleksi pendahuluan terhadap prinsip-prinsip, pengertian konsep dan generelasisasi pengetahuan.

3. Menyeleksi bahan, masalah/tugas tugas

4. Membantu dan memperjelas tugas/masalah yag dihadapi siswa serta peran masing-masing siswa.

5. Mempersiapkan kelas dan alat-alat yang diperlukan.

6. Mengecek pemahaman siswa terhadap masalah yang akan dipecahkan.

7. Memberi kesempatan kepada siswa untuk melakukan penemuan.

8. Membantu siswa dengan informasi/data jika diperlukan oleh siswa.

9. Memimpin analysis sendiri (Self-Analysis) dengan pertanyaan yang mengarahkan dan mengidentifikasi masalah.

10. Merangsang terjadinya interaksi antar siswa dengan siswa.

11. Membantu siswa merumuskan prinsip dan generalisasi hasil penemuannya.

Penerapan metode discovery learning memiliki nilai keunggulan dan kelemahan. Dalam buku srategi belajar-mengajar dikelas dijelaskan beberapa keunggulan penggunaaan metode Guided Dscovery Learning . diantaranya 
1. Siswa aktif dalam kegiatan belajar, sebab ia berfikir dan menggunakan kemampuan untuk menemukan hasil akhir.

2. Siswa memahami benar bahan pelajarannya, sebab mengalami sendiri proses menemukannya. Sesuatu yang diperoleh dengan cara ini lebih lama untuk diingat.

3. Menemukan sendiri bisa menimbulkan rasa kepuasan. kepuasan batin ini mendorongnya puas untuk menemukan penemuan lagi.

4. Siswa yang memperoleh pengetahuan dengan metode penemuan akan lebih mampu mentransfer pengetahuannya keberbagai konteks.

5. Metode ini melatih siswa untuk lebih banyak belajar sendiri. ${ }^{21}$

Sedangkan kelemahan dari metode discovery Learning adalah membutuhkan waktu belajar yang lebih lama dibandingkan dengan belajar secara menerima. implementasi metode Discovery Learning pada leson study masih memerlukan bantuan guru sebelum menjadi penemu murni. Oleh sebab itu metode penemuan ini disebut metode penemuan terbimbing (Guided Discovery Learning)

Diharapkan dalam penggunaan metode penemuan ini, mahasiswa dapat memaksimalkan kemampuan keterampilannya, idenya dalam menemukan hasil akhir tugas tersbut, sehingga kebiasaan dalam menemukan solusi dari berbagai masalah mahasiswa meningkatkan keterampilan soft skill yang menjadikan siswa siap hidup bermasyarakat

\footnotetext{
${ }^{21}$ Moh. Kanzunnudin, Dkk, Prosiding seminar..... hal 185
} 


\subsubsection{Teori Keterampilan}

Pengertian keterampilan atau skill Menurut Nadler (1986:73) pengertian keterampilan (skill) adalah kegiatan yang memerlukan praktek atau dapat diartikan sebagai implikasi dari aktivitas. Menurut Dunnette pengertian keterampilan adalah kapasitas yang dibutuhkan untuk melaksanakan beberapa tugas yang merupakan pengembangan dari hasil training dan pengalaman yang didapat. $^{22}$

Keterampilan tidak hanya membutuhkan training saja, tetapi kemampuan dasar yang dimiliki setiap orang dapat lebih membantu menghasilkan sesuatu yang bernilai dengan lebih cepat. Menurut Robbins, keterampilan dibagi menjadi 4 kategori yaitu:

1. Basic Literacy Skill : Keahlian dasar yang sudah pasti harus dimiliki oleh setiap orang seperti membaca, menulis, berhitung serta mendengarkan.

2. Technical Skill : Keahlian secara teknis yang didapat melalui pembelajaran dalam bidang teknik seperti mengoperasikan komputer dan alat digital lainnya.

3. Interpersonal Skill : Keahlian setiap orang dalam melakukan komunikasi satu sama lain seperti mendengarkan seseorang, memberi pendapat dan bekerja secara tim.

4. Problem Solving : Keahlian seseorang dalam memecahkan masalah dengan menggunakan loginya. ${ }^{23}$

$22 \mathrm{http}: / /$ cyber....

${ }^{23} \mathrm{http}: / /$ cyber... 
Terdapat empat aspek atau variabel yang mencirikan keterampilan. Keempat aspek itu adalah kecepatan, akurasi, bentuk, dan kesesuaian. Artinya, pertama keterampilan harus ditampilkan dalam batasan waktu tertentu, yang menunjukkan bahwa semakin cepat semakin baik. Kedua keterampilan harus menunjukkan akurasi yang tinggi sesuai dengan yang ditargetkan. Ketiga keterampilan pun harus dilaksanakan dengan kebutuhan energi yang minimal; (form atau bentuk menunjuk pada usaha yang ekonomis). Dan terakhir, keterampilan pun harus juga adaptif, yaitu tetap cakap meskipun di bawah kondisi yang berbeda-beda ${ }^{24}$

Keterampilan merupakan kegiatan yang berhubungan dengan kemampuan mengembangkan ide, memilih, menggunakan bahan, menggunakan peralatan dan teknik kerja. Keterampilan itu sendiri perlu disesuaikan dengan kebutuhan peserta didik dengan memperlihatkan aspek bakat, minat dan harapan peserta didik tersebut. tujuannya, agar mereka mampu mencapai penguasaan keterampilan bekerja (prevocational skill) yang secara integral ditunjang oleh keterampilan hidup (life Skill).

\subsubsection{Media Pembelajaran PAI}

Seorang guru profesional selain mampu memilih dan menggunakan media pembelajaran juga dituntut untuk membuat atau menyusun media pembelajaran

\footnotetext{
${ }^{24}$ http://kangmr.blogspot.co.id/2011/08/pengertian-keterampilanmacam-macam.html, 1 Desember 2014
} 
sendiri meskipun sangat sederhana, karena media sangat berperan dalam memberikan transfer knowlage pada siswa.

\subsubsection{Pengertian Media Pembelajaran PAI}

Kata media berasal dari bahasa latin Medius yang secara harfiah berarti tengah, perantara atau pengantar. Jadi media adalah pengatar pesan dari pengirim pada penerima pesan. Media adalah sebuah alat yang mempunyai fungsi menyampaikan pesan. Media pembelajaran adalah sebuah alat yang berfungsi dan digunakan untuk menyampaikan pesan pembelajaran. Pembelajaran adalah proses komunikasi antara siswa, pengajar, dan bahan ajar. Banyak batasan atau pengertian yan dikemukakan para ahli tentang media, diantaranya adalah: Asosiasi Teknologi dan Komunikasi Pendidikan (Asosociation of Education and Communication Technology (AECT). Media adalah sebagai bentuk dan saluran yang digunakan untuk menyampaikan pesan atau informasi. $^{25}$

Dari pengertian diatas, secara umum dapat dikatakan bahwa substansi dari media pembelajaran adalah bentuk saluran, yang digunakan untuk menyalurkan pesan, informasi atau bahan pelajaran kepada penerima pesan atau siswa dapat pula dikatakan bahwa media pembelajaran adalah berbagai jenis komponen dalam lingkungan

\footnotetext{
${ }^{25}$ Azhar Arsyad, Media Pembelajaran Edisi Revisi. Jakarta: PT Raja Grafindo Persada. 2011.hal 3
} 
dalam lingkungan siswa yang dapat merangsang siswa untuk belajar materi PAI.

\subsubsection{Manfaat Media Pembelajaran}

Sudjana \& Rivai mengemukakan manfaat media pembelajaranan dalam proses belajar siswa, diantaranya adalah

a. pengajaran lebih menarik perhatian siswa sehingga dapat menumbuhkan motivasi belajar

b. bahan pengajaran akan lebih jelas maknanya, sehingga dapat lebih di pahami siswa, dan memungkinkan siswa menguasai tujuan pembelajaranan

c. metode mengajar akan bervariasi, tidak semata-semata komunikasi verbal melalui penuturan kata-kata lisan guru, siswa tidak bosan, dan pengajar tidak kehabisan tenaga, apalagi kalu guru mengajar pada setiap jam pelajaran.

d. siswa dapat lebih banyak melakukan kegiatan belajar, sebab tidak hanya mendengarkan uraian guru, tetapi juga aktivitas lain seperti mengamati, melakukan, mendemonstrasikan, memerankan dan lain-lainya. ${ }^{26}$

\subsubsection{Jenis dan Kariteria Memilih Media Pengajara/Pembelajaran}

${ }^{26}$ Sudjana, N dan Rivai. Media Pengajaran.... hal. 2 
Dalam memilih ataupun membuat media untuk kepentingan pembelajaran seharusnya memperhatikan kriteria-kriteria sebagai berikut :

a.Ketepatanya dengan tujuan pengajaran ; artinya media pengajaran dipilih atas dasr tujuan-tujuan instruksional yang sudah ditetapkkan.tujuan-tujuan instruksional yang berisi unsur pemahaman, aplikasi, analisis, sintesis lebih memungkinkan digunakannya media pembelajaran.

b.Dukungan terhadap isi bahan pembelajaran ; artinya bahan pelajaran yang sifatnya fakta, prinsip, konsep dan generalisasi sangat memerlukan media agar lebih mudah dipahami siswa.

c.Kemudahan memperoleh media ; artinya media yang diperlukan mudah dipeoleh, setidak-tidaknya mudah dibuat oleh guru pada waktu mengajar. Media grafis umumnya dapat dibuat guru tanpa biaya yang mahal, disamping sederhana dan praktis penggunaannya.

d.Keterampilan guru dalam menggunakannya ; apapun media yang diperlukan syarat utama adalah guru dapat menggunakannya dalam proses pengajaran. Nilai dan manfaat yang diharapkan bukan pada medianny, tetapi dampak dari penggunaan oleh guru pada saat terjadinya interaksi belajar siswa dengan lingkungannya. 
e.Tersedia waktu untuk menggunakannya ; sehingga media tersebut dapat bermanfaat bagi siswa selama pengajaran berlangsung.

f. Sesuai dengan taraf berpikir siswa ; memilih media untuk pendidikan dan pengajaran harus sesuai dengan taraf berpikir siswa, sehingga makna yang terkandung didalamnya dapt dipahami oleh para siswa. $^{27}$

\section{BAB III HASIL PENELITIAN DAN INTERPRETASI}

Pelaksanaan Program Leson Study sebanyak 4 siklus dengan melalui 3 tahapan yakni Plan, Do dan see/Refleksi pada tiap siklusnya. Tahapan yang pertama adalah plan. Secara umum pada tahap ini kelompok LS menentukan dosen model dan materi yang akan disampaikan pada DO. Membuat PPT menentukan strategi strategi pembelajaranan, memilih metode dan menyusun SAP satuan Acara Perkuliahan dan Lembar Kerja Mahasiswa (LKM). Tahap selanjutnya setelah plan adalah DO.

Tahap kedua adalah DO, yaitu pelaksanaan pembelajaranan di kelas. Dosen model mengimplementasikan plan yang telah disusun dalam pembelajaran di kelas. Sedangkan dosen lain sebagai observer.

Setelah pelaksanaan DO, kelompok LS melakukan SEE/ Refleksi sebagai Feed Back guna memperbaiki plan selanjutnya. Setiap dosen/observer diberi kesempatan untuk memberikan masukan /komentar membangun untuk perbaikan plan selanjutnya

\footnotetext{
${ }^{27}$ Ibid ...hal 5
} 
secara bergantian. Sedangkan dosen model memberikan tanggapannya. Selalu berdiskusi untuk tercapainya pembelajaran yang aktif ,kreatif menyenangkan dan tujuan pembelajaran tercapai secara maksimal demi pendidikan yang lebih baik. Proses LS digambarkan sebagai berikut :

\section{Gambar 1. Gambar tahapan pada setiap siklus}

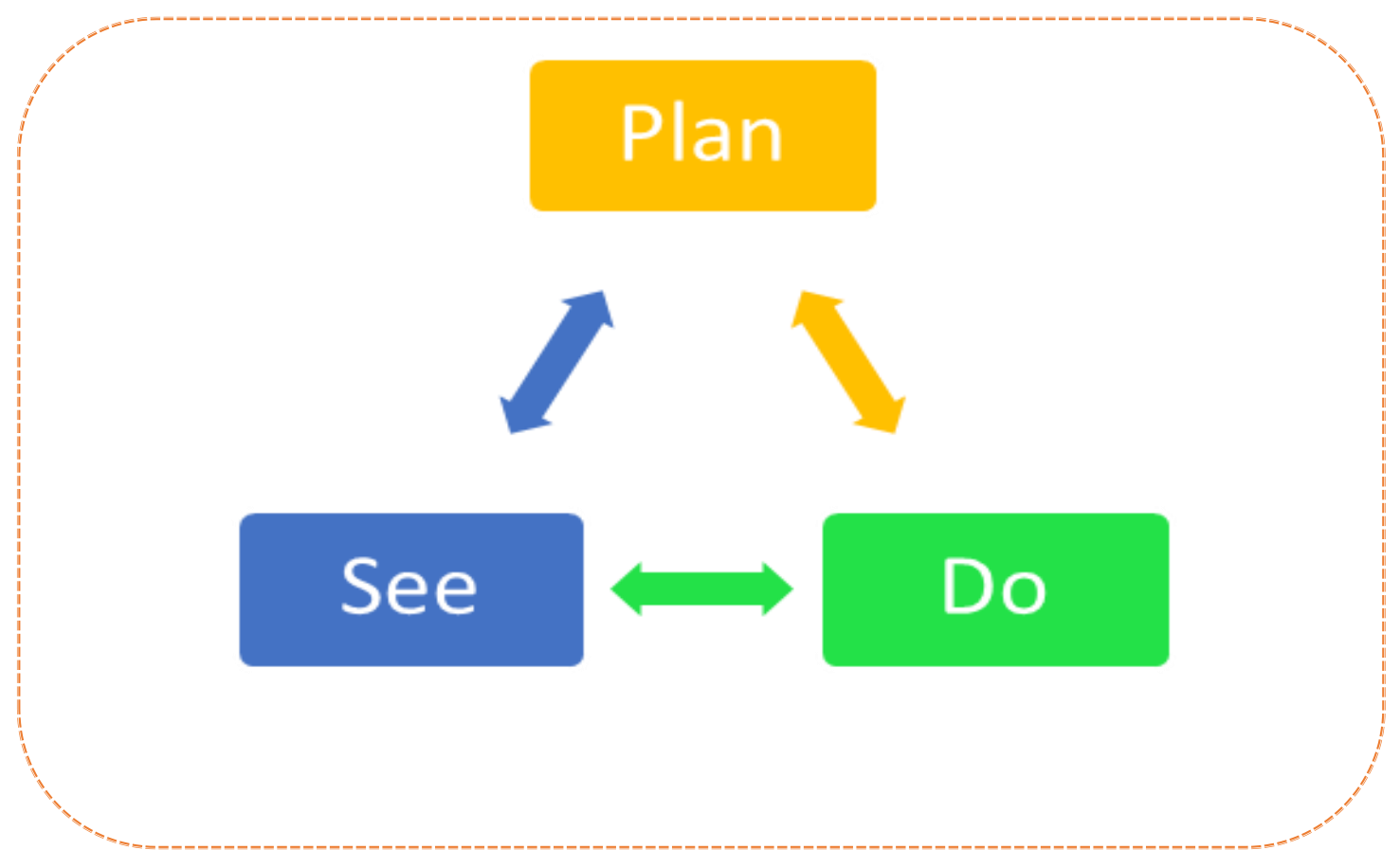

Pelaksanaan program Lesson Study ini diikuti oleh mahasiswa Pendidikan Agama

Islam Universitas Muhammadiyah Gresik semester 4 yang diikuti sebanyak 19 mahasiswa pada Mata Kuliah Teknologi dan Media Pembelajaran PAI. Adapun daftar nama mahasiswa sebagaimana berikut :

Table 1. Daftar Mahasiswa Yang mengikuti Lesson Studi

\begin{tabular}{|l|l|l|l|}
\hline NO & NIM & NAMA & SEMESTER \\
\hline
\end{tabular}




\begin{tabular}{|c|c|c|c|}
\hline 1. & 13512002 & Mu'arofah & 4 \\
\hline 2. & 13512004 & Meydi Arifana Putri & 4 \\
\hline 3. & 13512005 & Luthfiyani Siswanti & 4 \\
\hline 4. & 13512006 & Chairi Sulaiman & 4 \\
\hline 5. & 13512007 & Umi Fatmala & 4 \\
\hline 6. & 13512008 & Tutik & 4 \\
\hline 7. & 13512009 & Tri Yudha Setiawan & 4 \\
\hline 8. & 13512010 & Dewi Syahidah & 4 \\
\hline 9. & 13512011 & Rifqi Idillah & 4 \\
\hline 10. & 13512012 & Mira Megawati & 4 \\
\hline 11. & 13512013 & Amanu & 4 \\
\hline 12. & 13512014 & $\begin{array}{l}\text { Claudia Sabrina } \\
\text { Pangestu }\end{array}$ & 4 \\
\hline 13. & 13512015 & Nur Kholis & 4 \\
\hline 14. & 13512016 & Sayyid Ali Mustofa & 4 \\
\hline 15. & 13512017 & Ahmadi & 4 \\
\hline 16. & 13512018 & Dasi Silfiah & 4 \\
\hline 17. & 13512021 & Aprilian Fajar SIdiq & 4 \\
\hline 18. & 14512012 & Siti Khadijah & 4 \\
\hline 19. & 14512013 & $\begin{array}{l}\text { Dwi Khusnul } \\
\text { Khatimah }\end{array}$ & 4 \\
\hline
\end{tabular}


Sedangkan tim dosen pada pelaksanaan Lesson Study sebagai Dosen model dan Observer secara bergantian selama pelaksanaan Lesson Study. Adapun daftar nama dosen sebagai berikut :

\section{Tabel.2 Daftar Dosen yang mengikuti Tim Lesson Study}

\begin{tabular}{|l|l|l|}
\hline NO & NIY & \multicolumn{1}{|c|}{ NAMA DOSEN } \\
\hline 1. & 05119104018 & Drs. Man Arfa' Ladamay, M.Pd \\
\hline 2. & 05111403155 & Muyasaroh, M.Pd.I \\
\hline 3. & 05131408363 & Noor Amirudin, M.Pd.I \\
\hline 4. & 05131408362 & Ahmad Shofiyuddin, M.Pd.I \\
\hline
\end{tabular}

Sedangkan Implementasi metode Guided discovery Learning pada setiap siklus berupa pemberian tugas Lembar Kerja Mahasiswa (LKM) dengan memberikan potongan materi terutama materi tentang Pendidikan Agama Islam di tingkat SMP/ SMA yang harus dibuatkan media pembelajaran untuk mempermudah guru dalam mencapai tujuan pembelajaran. Dosen memantu dan berperan sebagai pendamping.

Secara umum gambaran langkah-langkah pembelajaran dengan metode Guided Discovery Learning yang di aplikasikan dalam pembelajaran adalah sebagai berikut :

Dosen memberikan kartu tentang materi. Mahasiswa bertugas membuat media pembelajaran sesuai dengan materi yang diterima. Siklus pertama pada Do pertama, sebagai dosen model adalah Ibu Muyasaroh, M.Pd.I dengan meteri membuat media sederhana dari kertas karton. Dosen melakukan penjelasan tentang media karton. Dosen menjelaskan melauli PPT tentang 
konsep dasar media pembelajaran. Bersama mahasiswa dosen melakukan Tanya jawab mengenai media pembelajaran. Kemudian, dosen mencontohkan media sederhana dari kertas berupa flash Card tentang membaca angka arab, menamabah, mengurangi sekaligus mendemonstrasikannya. Hasil dari demonstrasi dosen model disimpulkan oleh mahasiswa bahwa flash card yang diperagakan merupakan salah satu bentuk media pembelajaran.

Dosen berusaha mengarahkan denganmembentuk 4 kelompok dan memberikan Lembar Kerja Mahasiswa (LKM) berupa studi kasus tentang materi bahasa Arab. Mahasiwa diberi tugas membuatkan media sederhana untuk membantu menerangkan materi secara efektif dan efisien dengan menggunakan kertas karton. Dalam waktu 1 jam mahasiswa diharapkan mampu membuat media sederhana dari karton dan peralatan yang disiapkan. Mahasiwa saling berdiskusi dan menentukan media yang akan dibuat untuk menyampaikan materi. pada masing-masing kelompok, mahasiswa mampu menciptakan media sederhana sesuai dengan ide dan kreativitasnya. Siklus pertama disimpulkan sudah ada kesesuaian antara media yang dibuat dengan materi yang diberikan namun masih ada 2 kelompok yang kurang sesuai sehingga dalam prosentase $50 \%$. Media yang dibuat bervariasi bentuk dan fungsinya memperlihatkan adanya kreatifitas mahasiswa, namun waktunya masih berlebih dari waktu yang ditentukan yaitu 1 jam 30 menit.

Pelaksanaan DO yang ke 2, sebagai dosen model bapak Noor Amirudin, M.Pd.I, materi membuat media sederhana dari kertas karton, namun LKM yang diberikan sedikit berbeda, hal ini sebagai usaha dosen mengetahui sejauh mana peningkatan kreativitas mahasiswa. Sehingga pada LKM studi kasus materi pada semua kelompok di buat sama yaitu tentang thaharah. Meskipun mahasiswa merasa terbatas dalam materi, mahasiswa mampu mengambangkan pembahasan yang berbeda ada yang berwudhu, mandi junub dan tayamum. hasil observasi bahwa mahasiswa lebih cepat dalam menciptakan media dari waktu yang ditentukan yaitu $1 \mathrm{jam}$. Selain itu kesesuaian media sudah dengan materi75 \% karena ada satu kelompok yang kurang sesuai dan bentuk media yang dihasilkan beraneka ragam. 
Pelaksanaan Do ke 3 sebagai dosen pengampuh adalah bapak Ahmad shofiyuddin, M.Pd.I materi yang disampaikan adalah memanfaatkan IT sebagai media pembelajaran. Setelah diadakan Tanya jawab tentang IT munculah konsep Komputer. Sehingga dimunculkan LKM membuat Power Point yang kreatif. Mahasiswa diberikan potongan konsep materi dan mahasiswa segera membuat media Power Point Lebih cepat dari waktu yang disediakan yaitu 1 jam, bentuknya bervariasi dan terdapat kesesuaian dengan materi $100 \%$.

Pelaksanaan DO ke 4 dengan dosen model Ibu Muyasaroh, M.Pd.I, materi aplikasi IT dalam Media Pembelajaran. Fokus materi pada pemanfaatan internet untuk media pembelajaran. LKM disusun untuk membuat media berupa ppt dengan menampilkan video yang diperoleh dari pemanfaatan internet. Mahasiswa mendapatkan potongan materi yang berbeda dan di tugaskan mencari video dengan memanfaatkan internet sebagai media pembelajaran. Mahasiswa dengan terampil dan cekatan mengerjakan tugas LKM tersebut dan waktu yang digunakan lebih cepat yaitu : 35 menit dan terdapat kesesuaian antara materi dengan video yang dihasilkan 100\%. tercela. ${ }^{28}$

Hasil observasi implementasi metode Guided discovery Learning Adapun table peningkatan keterampilan sebagai berikut :

Table 3. hasil analisis peningkatan keterampilan mahasiswa dalam membuat media pembelajaran melalui metode Guided Discovery Learning

\begin{tabular}{|c|c|c|c|}
\hline SIKLUS & Variasi & Waktu & Kesesuaian Media \\
& & & dan Materi \\
\hline
\end{tabular}

\footnotetext{
${ }^{28}$ Data hasil studi kasus mahasiswa PAI semester 5 FAI UNMUH GRESIK, Mata Kuliah Media Pembelajaran PAI, dilaksankan hari Rabu jam 16.15 sampai 19.00
} 


\begin{tabular}{|c|c|c|c|}
\hline 1 & $\begin{array}{l}\text { Setiap kelompok } \\
\text { berbeda hasilnya }\end{array}$ & $\begin{array}{l}\text { Pembuatan media } \\
\text { lebih dari waktu yang } \\
\text { ditentukan yaitu } \\
1 \text { jam } 15 \text { menit }\end{array}$ & $\begin{array}{l}\text { Sudah sesuai antara } \\
\text { media dan materi } \\
\text { yang disampaikan } \\
50 \%\end{array}$ \\
\hline 2 & Produknya bervariasi & $\begin{array}{l}\text { Pembuatan media } \\
\text { tepat waktu yaitu } \\
1 \text { jam }\end{array}$ & $\begin{array}{l}\text { Sesuai media dan } \\
\text { materi } 75 \%\end{array}$ \\
\hline 3 & $\begin{array}{l}\text { Semua berupa PPT } \\
\text { namun bentuk } \\
\text { slidenya sangat } \\
\text { bervariasi }\end{array}$ & $\begin{array}{l}\text { Lebih cepat dari ke } \\
\text { waktu yang } \\
\text { ditentukan } \\
40 \text { menit }\end{array}$ & $\begin{array}{l}\text { Sesuai antara media } \\
\text { dan materi } 100 \%\end{array}$ \\
\hline 4 & $\begin{array}{l}\text { PPT dan video yang } \\
\text { diambil sangat } \\
\text { bervariasi }\end{array}$ & $\begin{array}{l}\text { Waktu lebih cepat } \\
\text { dari yang ditentukan } \\
\text { yaitu } 35 \text { menit }\end{array}$ & $\begin{array}{l}\text { Kesesuaian antara } \\
\text { media dan materi } \\
100 \%\end{array}$ \\
\hline
\end{tabular}

Melalui metode Guided discovery Lerning ini, memberikan kesempatan pada siswa untuk menemukan hasil karya terutama menghasilkan media pembelajaran yang variatif dan inovatif, sesuai dengan ide dan kreativitas masing-masing kelompok. Mahasiswa juga dituntut untuk aktif dan menemukan sendiri ide-idenya. Karena penemuan yang diciptakannya dapat mewujudkan kepuasan pada individu tersebut.

\section{BAB IV PENUTUP}


Berdasarkan hasil penelitian dapat disimpulkan bahwa melalui metode discovery Guided Learning mahasiswa mampu meningkatkan keterampilan mahasiswa dalam membuat media Pembelajaran PAI dengan indicator- indikator kecepatan waktu, kesesuaian antara media dan materi yang akan disampaikan dan bentuk dari media yang dihasilkan sangat variatif. Tiap siklus waktu yang digunakan semakin singkat. Hasil media pembelajaran beragam dan adanya kesesuaian antar amateri dan media yang dibuat hingga mencapai $100 \%$. Sebagaimana yang ditunjukan table 4 diatas.

\section{SARAN}

Setiap metode mempunyai keunggulan masing-masing dan seharusnya dosen yang baik adalah mampu menerapkan berbagai metode pembelajaran yang bervariasi seperti metode Guided Discovery Learning ini. 


\section{DAFTAR PUSTAKA}

Arikunto , S., Metodologi Penelitian Suatu Pendekatan Praktis (Jakarta : PT.Rineka Cipta 1997)

-------------, Prosedur Penelitian : Suatu pendekatan Praktek, (Jakarta : Rineka Cipta 2002)

Arsyad, A., Media Pembelajaran. (Jakarta : Raja Grafindo Persada, 2007)

-------------, Media Pembelajaran Edisi Revisi. Jakarta: PT Raja Grafindo Persada. 2011

Data hasil studi kasus mahasiswa PAl semester 5 FAI UNMUH GRESIK, Mata Kuliah Media

Pembelajaran PAI, dilaksankan hari Rabu jam 16.15 sampai 19.00

Marbuko, C. dan Ahmadi A., Metodologi Penelitian (Jakarta: Bumi Aksara,1997)

Haniyah, N., dan Jauhar M., Strategi Belajar-Mengajar di Kelas. Jakarta : Prestasi Pustaka

http://cyber-dakhlan90.blogspot.co.id/2012/09/keterampilan-dan-nilai-sebagai-materi.html

senin, 1 Desember 2014

http://kangmr.blogspot.co.id/2011/08/pengertian-keterampilanmacam-macam.html hari senin senin, 1 Desember 2014

http://repository.uinjkt.ac.id/dspace/bitstream/123456789/5033/1/101668-

SITI\%20MUTOHAROH-FITK.PDF selasa, 2 Desember 2014

http://eprints.umk.ac.id/3504/3/ARTIKEL_PROSIDING_2013.pdf senin, 8 Desember 2014

Desember 2014

http://kangmr.blogspot.co.id/2011/08/pengertian-keterampilanmacam-macam.html

Kanzunnudin, M., Dkk, (Prosiding seminar Nasional: 30 Maret 2013)

Nana, Sudjana., dan Rivai. Media Pengajaran. Bandung: CV Sinar Baru Bandung, 2010

Sani, R. A., Inovasi Pembelajaran.(Jakarta PT : Bumi Aksara, 2013)

Sugiyono. Metode Penelitian Pendidikan Pendekatan Kuantitatif, Kualitatif dan R\&D.(Bandung : Alfa Beta 2010)

Undang-Undang Republik Indonesia, No.20 Tahun 2003 tentang Sistem Pendidikan Nasional. BAB II pasal 3. 